NBER WORKING PAPER SERIES

\title{
USING EXPERIMENTAL ECONOMICS TO MEASURE THE EFFECTS OF A NATURAL EDUCATIONAL EXPERIMENT ON ALTRUISM
}

\author{
Eric Bettinger \\ Robert Slonim \\ Working Paper 11725 \\ http://www.nber.org/papers/w11725 \\ NATIONAL BUREAU OF ECONOMIC RESEARCH \\ 1050 Massachusetts Avenue \\ Cambridge, MA 02138 \\ October 2005
}

We are grateful for research support from James Carlson, Luke Coffman, Samir Dalia, Matthew Dellibovi, Muhammid El-Zoghbi, Matt Ennis, Liz Falvo, Alissa Kumley, Stephen Leider, Rohit Reddy, Erin Riley and Christine Uhlmansiek. We also thank Ellen Garbarino and Jim Rebitzer for many helpful comments on earlier versions of this paper and seminar participants at Case Western Reserve University, the Education Program at the NBER's Summer Institute 2002, the Midwestern Economic Association Meetings 2001, the International Economic Science Association Meetings 2002, the Middlebury Conference on Field Experiments 2003, and the Research Environment Development Series at Case Western Reserve University 2003. We greatly appreciate the financial support of The Armington Fund, The National Science Foundation Grant No. 0214308, The Russell Sage Foundation, The Upjohn Institute, and The Weatherhead School of Management. We also greatly appreciate Central Catholic High School in Toledo for use of their facilities. Bettinger completed much of this research while a visiting scholar at the American Academy of Arts and Sciences. The views expressed herein are those of the author(s) and do not necessarily reflect the views of the National Bureau of Economic Research.

(C)2005 by Eric Bettinger and Robert Slonim. All rights reserved. Short sections of text, not to exceed two paragraphs, may be quoted without explicit permission provided that full credit, including $\odot$ notice, is given to the source. 
Using Experimental Economics to Measure the Effects of a Natural Educational Experiment on Altruism

Eric Bettinger and Robert Slonim

NBER Working Paper No. 11725

October 2005

JEL No. I2, C9

\begin{abstract}
Economic research examining how educational intervention programs affect primary and secondary schooling focuses largely on test scores although the interventions can affect many other outcomes. This paper examines how an educational intervention, a voucher program, affected students' altruism. The voucher program used a lottery to allocate scholarships among low-income applicant families with children in K-8th grade. By exploiting the lottery to identify the voucher effects, and using experimental economic methods, we measure the effects of the intervention on children's altruism. We also measure the voucher program's effects on parents' altruism and several academic outcomes including test scores. We find that the educational intervention positively affects students' altruism towards charitable organizations but not towards their peers. We fail to find statistically significant effects of the vouchers on parents' altruism or test scores.
\end{abstract}

Eric Bettinger

Weatherhead School of Management

Peter B. Lewis Building, RM 266

Case Western Reserve University

Cleveland, OH 44106-7235

and NBER

bettinger@cwru.edu

Robert Slonim

262 Peter B. Lewis Building

Department of Economics

Case Western Reserve University

11119 Bellflower Road

Cleveland, OH 44106-7235

robert.slonim@cwru.edu 


\section{Introduction}

Educational interventions can affect both academic and non-academic outcomes [Figlio and Ludwig 2000, Greene 2000, Angrist, Bettinger, Bloom, King, and Kremer 2002, Jacob and Lefgren 2003].

Test scores are certainly one of the more important measures of the success of an educational intervention since they reflect academic achievement and potential future earnings [Levy, Murnane and Willet 1995]. Yet, test scores are not the only measure of the success of an educational intervention. ${ }^{1}$ Bowles, Gintis and Osborne [2001, pp. 158] argue that test scores are an imperfect measure of the effects of schooling and that economists "need broader indicators of school success, including measures based on the contribution of schooling to behavioral and personality traits.” Heckman [2000, pp. 4] further argues that "[t]he preoccupation with cognition and academic 'smarts' as measured by test scores to the exclusion of social adaptability and motivation causes a serious bias in the evaluation of human capital formation.” Indeed, if the effect of an educational intervention on test scores and non-academic outcomes are not highly correlated, then educational programs can be successful without ever affecting test scores.

To understand the possible non-academic effects of educational interventions, this paper studies the effect of a voucher program on altruism. We study the effect of this educational intervention on altruism for several reasons. First, economists increasingly recognize the role altruism plays in the economy. For example, altruism can generate positive externalities [Bergstrom, Blume and Varian, 1986; Andreoni 1988] and can positively influence capital accumulation, intergenerational transfers, marriage, and the environment [e.g. Dynan et al. 2002, Andreoni et al. 2003, MacDonald and Koh 2003, Jouvet et al. 2000]. Second, research by economists [e.g. Harbaugh and Krause 2000] and

\footnotetext{
${ }^{1}$ For example, Angrist et al. [2002] evaluate the effect of educational vouchers on both test scores and additional outcomes such as teen pregnancy and marriage rates; Figlio and Ludwig [2000] examine the effects of private schooling on teenage sexual activity and drug use; Greene [2000] looks at the effects of private schooling on future voting; and Jacob and Lefgren [2003] examine the effects of school holidays on juvenile crime. In addition, Becker [1993] noted that empirical evidence shows that more education, among other outcomes, improves health, reduces smoking, increases voting and increases knowledge about birth control.
} 
psychologists [e.g. Bryan and Walbek 1968, Froming 1985] suggest that altruism is developing among young school-age children. Third, schools and educational interventions such as the voucher program we study may affect altruism. A school's role in socialization may increase altruism by teaching pupils to share and help others in their classroom, school and community. For instance, both private and public schools claim to teach charity or altruism as part of their curriculum. ${ }^{2}$ Moreover, many educational initiatives provide free or discounted charitable services to students and their families which may affect students' subsequent level of altruism by increasing a sense of reciprocity to society due to the programs' charitable services.

Even though educational interventions can affect the development of altruism (and other nonacademic outcomes), economists continue to primarily use test scores as the central metric of their success. This is especially the case for educational voucher programs where research has largely focused on whether voucher winners' test scores improve relative to some control group [Rouse 1998, Myers, Peterson, Mayer, Chou, and Howell 2000, Angrist et al. 2002, Krueger and Zhu 2003]. ${ }^{3}$ In the case of vouchers, this focus on test scores is easy to understand. Test scores are relatively inexpensive to collect and, with the advent of high-stakes testing, they are the primary metric by which the federal and most state governments judge schools. However, the focus on test scores seems at odds with voucher proponents' claims that greater choice is justifiable by the fact that non-academic outcomes and programs (e.g. safety, discipline, peers or curricula that promote health or a specific moral code) influence parents' educational decisions for their children [Harrison and Kennison 1993]. While we concur that test scores are important and provide some estimates of

\footnotetext{
${ }^{2}$ Almost all of the private schools in our sample are Catholic, and in our pilot study interviews, private school principals claimed that their schools teach children to be "charitable." Additionally, many public schools also attempt to teach altruism through such programs as "Character Counts" (http://www.charactercounts.org/) or other "character education" initiatives (e.g. Williams, Yanchar, Jensen, Lewis 2003).

${ }^{3}$ Most voucher programs use randomization to allocate vouchers. The research to date takes advantage of this randomization to estimate the effects of the voucher. Most studies, like this one, focus on the reduced form effect of the voucher since voucher programs often affect several facets of students' lives (e.g. private schooling, motivation, income). We discuss this further in Section 3 of this paper.
} 
the effect of a voucher program on children, given the importance of altruism and its development and given the claims that vouchers may affect non-academic behaviors including altruism [Greene 1998], we investigate the effects of vouchers on altruism.

Measuring children's altruism is not without difficulty, however, since economists typically measure altruism through gifts that are observable in adults, e.g., through household surveys or tax records, but that are typically unobservable in children. Fortunately, economists have developed laboratory methods to help measure and quantify altruism. Specifically, economists have developed "dictator" games [e.g., Hoffman, McCabe and Smith 1996] to present subjects with situations in which they can exhibit altruism [Eckel and Grossman 1996, 1998]. Besides testing theory and quantifying altruism, these experiments study the determinants of altruism such as gender, race, age, deservingness of recipients, social distance and the relative costs of altruism [e.g., Andreoni and Vesterlund 2001, Eckel and Grossman 1998, Harbaugh and Krause 2000]. ${ }^{4}$ Using similar methods, we measure the effect of vouchers on altruism. Thus, this paper measures the effect of an educational intervention on altruism and presents a novel use for the experimental economic laboratory to assess policy intervention. ${ }^{5}$

Our use of laboratory experiments in a field setting extends recent efforts by economists. For example, experimental laboratory methods have been used in the field to study discrimination [Fershtman and Gneezy 2001 and List 2004], discount rates [Eckel, Johnson and Montmarquette 2005 and Harrison, Lau and Williams 2002], social capital [Karlan 2003], auction theory [List and

\footnotetext{
${ }^{4}$ Studying altruism using decision-making experiments is also potentially beneficial compared to survey methods since research shows that respondents tend to overestimate their charitable contributions [Fehr et al. 2003]. Additionally, psychologists have studied reciprocity and generosity in children for decades, with experimental studies demonstrating that children share with "charities" without receiving external rewards for their generosity [e.g. Midlarsky and Bryan 1967].

${ }^{5}$ Of course, economists frequently use natural and randomized field experiments, such as negative income tax and audit studies, to examine economic phenomena. The distinction made here is the laboratory setting. The laboratory setting not only allows us to measure outcomes of interest in populations in which the outcomes would otherwise be hard to observe, but also allows us to measure the outcomes quickly, which is perhaps a relatively more important concern for policy makers than for researchers.
} 
Lucking-Reiley 2000 and Lucking-Reiley 1999] and charitable giving [List and Lucking-Reiley 2002]. We extend this line of laboratory field research to test an intervention program.

Data for this research come from the Children's Scholarship Fund (CSF) of Toledo, Ohio. CSF offers 4-year renewable, private school scholarships to K-8 ${ }^{\text {th }}$ grade students in Northwest Ohio. To be eligible, students must qualify for federal reduced/free lunch programs. In 1998, almost 2,500 families applied for CSF scholarships, and CSF awarded more than 1,500 scholarships by lottery. ${ }^{6}$ Within this population, we use experimental economic methods to compare levels of altruism between voucher lottery winners and losers. We also use similar methods to measure altruism of parents whose children applied for scholarships. Gathering the same experimental data for both parents and children allows us to detect the extent to which family background versus the educational intervention affects the children's altruism. Further, the extent to which children's behavior is correlated with parental outcomes is of interest itself.

We find that voucher lottery winners were more altruistic towards charitable organizations than unsuccessful applicants: voucher winners gave over 20 percent (or about $\$ 0.75 / \$ 3.33$ ) more than losers to charitable organizations. This increased altruism, however, does not extend to greater generosity to peers. We also find that parent's altruism does not explain children's altruism. Similar to some past studies [e.g. Krueger and Zhu 2003], we find little evidence that voucher winners have significantly higher test scores although the estimated effects on test scores are noisy. Finally, we find that test scores and altruism are not correlated. These latter two findings (that vouchers significantly affect altruism and that test scores are uncorrelated with altruism) suggest that studies focusing exclusively on test scores may understate the overall impact of an educational intervention program.

\footnotetext{
${ }^{6}$ The national office of CSF controlled the application process. In Northwest Ohio, the scholarships were advertised through radio, newspaper, and television advertisements.
} 


\section{Experimental Protocols and Data}

We focus on the sample of applicants to the Children's Scholarship Fund of Toledo (CSF) in 1998. CSF offers 4-year, renewable, private school scholarships to low-income families in Northwest Ohio. To be eligible, students had to qualify for federal reduced/free lunch programs and either be entering or attending elementary or junior high school. Scholarships are renewable so long as students attend private school. We focus on the 2,424 families who applied for scholarships in 1998. ${ }^{7}$ CSF partitioned this group into two parts: those who had self-reported that at least one child was attending private school at the time of the lottery $(1,265)$ and those who had none in private schools $(1,159)$. CSF held separate lotteries for each group. We refer to these lotteries as the "private" and "public" school lottery. If a family won the lottery, all children were eligible to use the voucher. For each child using the voucher, the voucher would pay for one-half of the private school tuition. The random assignment of scholarships facilitates identification by allowing us to use unsuccessful applicants as a comparison/control group for the scholarship winners.

We attempted to contact a random sample of 438 families representing almost 900 children. We attempted to survey and invite this sample to attend an "evaluation event" where we conducted our experiments, administered a standardized test (California Achievement Test) and administered an additional survey to parents. ${ }^{8}$

\section{A. Experimental Protocols for Altruism}

\footnotetext{
${ }^{7}$ The program was small enough relative to the size of Toledo's public schools that it likely did not affect the neighboring public school system. In years before and after 1998 the number of scholarships CSF offered was substantially smaller than in 1998, thus we focus on the 1998 sample.

${ }^{8}$ Angrist et al. [2002] and Myers et al. [2000] gathered test score data at similar events. We also gathered data on time-preferences and self-confidence and these other measures are discussed in Bettinger and Slonim [2004] and Slonim and Bettinger [2005], respectively. Appendix 1 describes the data collection procedures in more detail.
} 
To measure altruism, we had all subjects make decisions in six "dictator" games. ${ }^{9}$ For the first three, we matched subjects to different non-profit organizations: The American Red Cross, The Make-A-Wish Foundation and The Children's Scholarship Fund. We used three organizations to control for the possibility that different degrees of personal association can influence generosity (for instance, greater personal association may cause greater reciprocity). In each decision, children were endowed with $\$ 10$ (in Toys-R-Us gift certificates) and parents were endowed with $\$ 50$ in cash. After reading instructions aloud and reviewing a brief written description of each organization, including a simplified version for children, subjects chose how much of their endowment to keep for themselves and how much to give to the organization. ${ }^{10}$ Appendix 2 shows the decision sheet and description of each charity we presented to the students. Eckel and Grossman [1996 and 2003] and Eckel, Grossman and Johnston [2005] use a similar pairing of college students with charitable organizations to measure other determinants of altruism. ${ }^{11}$

In the last three dictator games, we again endowed children with $\$ 10$ in gift certificates and parents with $\$ 50$ in cash. In each of these decisions, each subject chose how much of the endowment to keep and how much to give to another person. Any amount given was multiplied by an exchange rate before being given to the other person. The exchange rate varied from 50 percent (so each dollar given became $\$ 0.50$ to the other person) to 100 percent and then to 150 percent. The recipient of the amount given away (i.e., the other person) was another child at the event for the children and another parent at the event for the parents. At the end of the session we randomly and anonymously selected who these recipients would be. Subjects did not know who they would be

\footnotetext{
${ }^{9}$ The decision-making protocols for the generosity measures were adapted from Harbaugh and Krause [2000].

${ }^{10}$ To maximize the likelihood that the subjects believed we would send the organization the money, we had envelopes prepared. We also gave subjects the option to receive a "thank you" letter from the organization.

${ }^{11}$ We verified that parents felt that benefits from the charitable organizations went to deserving people. At the completion of the decision-making exercises we had parents (in the survey) respond on a scale from 1 (strongly disagree) to 5 (strongly agree) to the statement " $(\mathrm{t})$ he recipients of the [charitable organization name] are deserving of support." For the Red Cross, Make-A-Wish and Children's Scholarship Fund, the average responses were 4.72, 4.80 and 4.79, respectively and only 3.4 percent of respondents assessed the deservingness of these organizations less than 4.
} 
paired with at the time of the decision, nor did they ever find out. We did not collect this generosityto-other-children measure in sessions with fewer than 5 children. To control for wealth effects, at the end of each session we randomly selected approximately one parent and one child per every five attendees and paid them for one of the decisions they made. ${ }^{12}$ To avoid experimenter bias, during the sessions the experimenters did not know whether subjects were voucher lottery winners or losers. $^{13}$

We examine the amounts given to the three specific organizations to potentially capture different aspects of altruism. Generosity to charities often comes from an appreciation for non-profit organizations' goals and especially the neediness of the recipients that the organizations attempt to help. However, direct and/or indirect reciprocity can also be a motivation to give to non-profit organizations. Thus, among the three charities that we included in the experiment, we include the Children's Scholarship Fund - the same organization that gives the scholarships. Comparison of amount given to each organization between lottery winners and losers will allow us to partially distinguish between the amounts given being motivated by the organizations' goals and the amounts given being motivated by reciprocity. ${ }^{14}$

We further examine the two constructs of amount given to charities and amount given to peers to capture additional dimensions of altruism. Economists recognize that individuals may show different levels of altruism to charities than they show to peers: for instance, Eckel and Grossman

\footnotetext{
12 Wealth effects in an experimental context occur when payments made to a given subject in an early decision impact their behavior in subsequent decisions. The experimental economics literature extensively discusses the use of a random selection mechanism to control for wealth effects [e.g., Davis and Holt, 1993]. The idea is that by being paid for a random subset of decisions, or just one, subjects anticipated wealth for a given decision, based on all other decisions, is essentially identical, thus placing them at the same point on their utility curves.

${ }^{13}$ All data was collected single blind (subjects did not know the research objectives) and single anonymous (subjects did not know any other subject's choices).

${ }^{14}$ In all sessions, we presented the charities in the same order - American Red Cross, Children's Scholarship Fund, and then Make-AWish Foundation. While this ordering may have influenced students' donations to individual charities, the ordering was symmetric across winners and losers of the voucher lottery. Hence, the ordering should not bias the estimates of the differences between winners and losers, though it may skew some comparisons of overall donations across the three charities. We will find that students give slightly more (marginally significant) to Make-A-Wish than CSF, which could be due to differences in the perceived deservingness of the charities, or possibly due to the order in which the Make-A-Wish decision came before the CSF decision.
} 
[1996] show that college students give more to a non-profit organization than to peers in anonymous dictator games. While generosity to charities may come from an appreciation for non-profit organizations’ goals, generosity to peers may come from concern for fairness [e.g., Fehr and Schmidt 1999, Bolton and Ockenfels 2000]; for example, people may be motivated to give to peers who are less fortunate than themselves to reduce a loss of utility from inequitable outcomes. Giving to peers therefore captures an element of altruism motivated by concern for others and/or for fairness whereas giving to charities captures an element of altruism motivated by concern for non-profit organizations' goals. Thus, vouchers lottery winners may demonstrate greater altruism differentially across the amounts given to each charity and/or give different amounts to the charities than to peers depending on the relative importance of the voucher programs' influence on each dimension of altruism.

\section{B. Descriptive Statistics}

Table 1 shows descriptive statistics for the 2,424 families who applied to CSF in 1998. In the public school lottery, successful applicants (lottery winners) had statistically similar household sizes and proportions of children previously attending a private school, but averaged about $\$ 2,200$ less income. While the income difference at the means is significant, the difference between the medians is not significant and is only about $\$ 600$. A few outlier observations cause the difference in means.

As we mentioned earlier, the public lottery included families where no child was enrolled in private school at the time of the lottery while the private lottery included any family with at least one child currently enrolled in private school. This division between families with previous private school experiences and those without was not a perfect sorting. As Table 1 shows, about 10 percent of the public school lottery had at least one child who was attending private school prior to the lottery. These "leakages" occurred because at the beginning of the application process, some phone 
workers assigned families to the public school lottery if at least one of their children was currently attending public school. These incorrectly assigned families participated in the public school lottery but were not more likely than other public school lottery winners to have won the voucher lottery.

In our pilot data collection, we found that the voucher had little effect on private school attendance among students in the private school lottery. In fact, almost all of the applicants attended private school at the time of the lottery. If one objective of the voucher program is to change attendance from public to private school, then focusing on the lottery among the private school attendees would not yield a true treatment since they were all already attending private schools. In our sample, we include a small number of these students because they may help us distinguish between possible mechanisms for the voucher to have affected students. However, since we are primarily interested in measuring the effects of the voucher on students who may have changed from public to private schools, our attempted survey and experimental sample focused largely on families from the public school lottery (390 of the 438).

For the preliminary survey, we contacted a majority of families by phone, mail, and household visits between March and October 2001. ${ }^{15}$ Our survey response rate in the public school lottery was 61 and 67 percent for unsuccessful and successful applicants, respectively. This was much higher than anticipated since our contact information was 3 to 4 years old and was especially higher than anticipated given that more than 25 percent of the sample had moved during these 3 to 4 years. Moreover, the response rate is similar (if not better) than other voucher studies: for instance, Angrist et al. [2002] report a response rate of 52 percent for students contacted after 3 years and Myers et al. [2000] reports a 65 percent response rate after 2 years. The 67 and 61 percent response rates across voucher winners and losers are symmetric (i.e., statistically identical), thus increasing the likelihood of the internal consistency of the estimates of the voucher effect [Angrist 1997]. Further, we find no

\footnotetext{
${ }^{15}$ The complete protocol (attempts, contact methods, resources for locating addresses) is available upon request from the authors.
} 
significant differences between winners who responded and winners who did not and we find no significant differences between losers who responded and losers who did not.

Table 1 shows that 39 percent of unsuccessful families were single parent homes in the public school lottery, 23 percent had one parent who graduated from college and that African-Americans made up 57 percent of the sample. Race is the only variable in Table 1 that suggests differences between lottery winners and losers. There were a lower proportion of blacks among winners who responded than among losers who responded. This cannot be the result of non-random voucher assignment, however, since CSF did not collect information on race prior to the lottery. ${ }^{16}$ The difference is possibly due to some non-response pattern in our survey. We control for race throughout our empirical results to control for this difference.

Table 2 shows student characteristics among the surveyed families. We surveyed the parents of 471 students of which 218 had not won the voucher lottery. On average, these students were 10 years old, in the fourth grade, and just over half were female. Column 2 compares the differences between lottery winners and losers. There are no significant differences between lottery winners and losers in age, gender or grade, but consistent with the data in Table 1, African-American voucher winners were less likely to respond than African-American lottery losers.

Columns 3 and 4 of Table 2 compare students who attended our "evaluation events.” Students who attended were insignificantly younger than those not attending, and African-Americans were more likely to attend. Column 5 reports the differences among winners and losers who attended. As before, African-American lottery winners were less likely than African-American lottery losers to attend the event, and we had more representation from winners than losers in the private school lottery.

\footnotetext{
${ }^{16}$ Since CSF observed names, they may have been able to discriminate by observing distinctively African-American names; however, the magnitude of CSF's operation makes this discrimination unlikely (e.g., Bertrand and Mullianathan 2004). CSF had over 1.25 million applicants nationwide in 1998 and had only one person to manage the lists and conduct the selection lotteries for all their sites.
} 


\section{Voucher Effects on Academic Outcomes}

Before reporting the voucher effects on altruism, we show estimates of the voucher effects on educational outcomes and the correlations between educational outcomes and altruism. The effect on educational outcomes from the intervention provides comparison to previous studies. The correlation between educational outcomes and altruism provides an indicator of whether educational outcomes may be sufficient statistics for the voucher program's broader effects.

Throughout the paper, we estimate the effect of the "intention to treat" rather than the effect of the "treatment on the treated" (i.e. the effect of using the voucher) or the effect of private schooling. The "intention to treat" is often referred to as the effect of receiving the voucher, and to measure the effect, we compared outcomes of lottery winners and losers, even if the winners declined the scholarship. Besides being perhaps the parameter of most interest to policymakers [Rouse 1998], the "intention to treat" is one effect for which we can produce an unbiased estimate. ${ }^{17}$ Because of randomization, simple t-test comparisons of voucher winners and losers can identify the effects of the voucher [Angrist and Krueger 1999]. We also use the following regression to assess the effects of the voucher:

$$
y_{i}=a \dashv \beta(\text { WonVoucher })_{i} \dashv \not X_{i} \dashv \varepsilon_{i}
$$

where $y_{i}$ is an outcome for student $i$ and $X_{i}$ includes controls for race, gender, age, family income, house size, and whether the family was part of the private school lottery. Throughout the tables, we report standard errors that correct for correlation across siblings.

\footnotetext{
${ }^{17}$ The "intention to treat" parameter is not the only parameter of interest to policy-makers or researchers. The effect of the "treatment on the treated" estimates the effect of voucher usage on student outcomes. Unbiased estimation of the effect of the "treatment on the treated" requires that we compare winners who took up the voucher to losers who would have taken up the voucher had they been offered. Since unobservable characteristics may determine take-up, creating an appropriate control group may be implausible, and any estimates that we may generate of this effect would not be defensible without additional information. Economists have also long been interested in estimating the effects of private school [e.g. Neal 1997]. Some have debated whether vouchers may facilitate identification of the effect of private schools [e.g. Rouse 1998, Angrist et. al 2002]. While vouchers may affect the likelihood of attending private schooling, it still may not be a suitable instrument since winning a voucher lottery may affect students' outcomes for reasons other than the voucher (e.g. income effects, reciprocity to charities).
} 
Table 3 reports estimates of Equation 1 on academic outcomes. The first two rows show the effects that the voucher had on the type of school that students attended. At the time of our survey 3-4 years after applications were made, 21 percent of unsuccessful voucher applicants were attending private school. The voucher intervention increased private school attendance by an additional almost 23 percent. This effect is highly significant. We also find significantly less voucher winners than losers were suspended. Fewer voucher winners being suspended may be a positive outcome but may also be due to differences in public/private school disciplinary policies and thus may not be a "true" change in behavior. We also find no evidence that voucher winners were more or less likely to have repeated a grade.

Table 3 also shows results for the mathematics exams administered to most of the event participants. $^{18}$ We administered exams and computed the normal curve equivalents for each student on each exam. Because we have a small sample size, we "stack" the test scores creating two observations for most of our sample. Students scored on average in the $48^{\text {th }}$ percentile with a standard deviation of 23 percentage points. When we compare test scores without controlling for student covariates, we find that voucher winners scored just under one percentage point higher. With covariates, students who won the voucher lottery score an insignificant 0.11 percentage points higher than unsuccessful applicants. The standard error bands are generous on these estimates because of the small sample size and we cannot rule out test score effects that may be positive or negative and as large as 1/3 of a standard deviation in magnitude. Nonetheless, the test score results are qualitatively consistent to those found in voucher studies from New York City [Mayer, Peterson, Myers, Tuttle, and Howell 2002, Myers et. al 2000, Krueger and Zhu 2003] where no significant test score effects were detected.

\footnotetext{
${ }^{18}$ There were 212 students who actually attended the "evaluation events." These events lasted up to 2.5 hours and several families left before the test administration. In the initial events, we also did not anticipate a need for tests for students above $7^{\text {th }}$ grade. We were thus unable to test a few students who came to these initial events.
} 
A typical voucher study might stop at this point. We found no significant effects on test scores. Thus, if test scores are a sufficient statistic for all outcomes of interest, then we need not proceed further. However, this is not the case. If test scores were a sufficient statistic for other outcomes, then we should see test scores correlate with outcomes even if there is a "true" test score effect that is not measurable because of our small sample size. When we compare student test scores to our measures of altruism, we find small correlations. The correlation between students' math scores and the amount they give to the Red Cross, the Make-a-Wish Foundation, and the Children's Scholarship Fund are only .06, .06, and .09 respectively. The correlations with the three measures of giving to their peers are all slightly negative at -.02, -.01, and -.13. Thus, test scores are not a sufficient statistic for our measures of generosity, and the next section explores the extent to which vouchers may affect students' altruism.

\section{Voucher Effects on Altruism}

Table 4a presents OLS regressions that show the determinants of the amount children give to charitable organizations and to each other. The dependent variable is the amount that a student gives to the respective entity. The first three columns report estimates of Equation 1 where the dependent variable is the amount given to the respective charity. Columns 4 and 5 report the effects of vouchers when we "stack" the regressions across the charities. ${ }^{19}$ Column 6 reports the estimated amount given to peers. We report the means for the voucher lottery losers in the first row.

On average, voucher lottery winners give 40 percent $(\$ 1.19 / \$ 3.00)$ more to the Red Cross than voucher lottery losers, and likewise 14 percent $(\$ 0.52 / \$ 3.73)$ and 22 percent $(\$ 0.71 / \$ 3.27)$ more to Make-A-Wish and CSF, respectively. Averaging across all three charities, voucher winners give 23 percent $(\$ .75 / \$ 3.33)$ more than voucher losers. Controlling for the covariates, we find that winning

\footnotetext{
${ }^{19}$ In the stacked regressions, we include dummy variables for the respective charities. As before, we control for correlation across siblings.
} 
the voucher significantly increases giving to the Red Cross ( $\mathrm{t}=2.66, \mathrm{p}=.009)$. The voucher also has a positive though insignificant effect on giving to Make-A-Wish and the Children's Scholarship Fund (CSF: $\mathrm{t}=1.43, \mathrm{p}=.157$; Make-A-Wish: $\mathrm{t}=0.99, \mathrm{p}=.322$ ). Column 4 shows that in the "stacked" regressions voucher lottery winners give a marginally significant amount more than voucher lottery losers ( $\mathrm{t}=1.77, \mathrm{p}=.076)$. When we control for the size of the child's parental contribution to the same charity in the stacked regression (Column 5), we find that the estimated voucher effect slightly increases from 0.75 to 0.78 and is slightly more significant ( $\mathrm{t}=1.87, \mathrm{p}=.061)$.

The final column of Table 4a shows the determinants of how much children gave to other children. In contrast to the amounts children gave to the charitable organizations, we fail to find a significant effect of the voucher on the amount children gave to each other. The point estimate is negative, close to zero and statistically insignificant. This result suggests that the reason lottery winners gave more to charities is not motivated solely by a concern for fairness.

The estimates in Table 4a also present results that previously have been undocumented as well as other results that we can compare to past studies for robustness. Previously undocumented, we find a positive but insignificant relationship between parental and child giving to charities and peers in the stacked regressions (Columns 5 and 6). This relationship is marginally significant for the amount that children give to the Red Cross and is directionally positive for the amount children give to Make-A-Wish and CSF.

To validate our measures, we compare coefficients presented in Table 4a with those examined by other researchers in similar experiments. Our age and gender estimates on giving are consistent with results reported in Harbaugh et al. [2000]; older children give more (significantly to the 
charities) and boys give less (significantly to their peers). ${ }^{20}$ The current data thus show that Harbaugh et al.'s results, which focus on a relatively suburban white population, are robust to our sample consisting of a majority of urban African-American children. Also, similar to the behavior of college students reported in Eckel and Grossman [1996], we find that children in first through eleventh grade, as well as their parents, give more to charities than to peers. For instance, aggregating across voucher winners and losers, we find that children on average gave \$3.77 (38 percent) of their $\$ 10$ endowment to the charities but only $\$ 2.61$ (26 percent) to other children. Regressions (not shown) indicate that these differences are highly significant. Finally, similar to college student's behavior reported in Andreoni and Vesterlund [2001], we find that the exchange rate has a negative but insignificant affect on the amount children give to their peers. These comparisons indicate that our measures are externally valid with, and provide robustness to, the previous experimental evidences on the determinants of altruism with different populations.

In Table 4b, we test alternative specifications for the robustness of these results. These estimates of the stacked regressions are based on ordered probits and tobits. These approaches are more parametric in nature and thus may have advantages over the OLS estimates. The ordered probit model may capture the fact that increasing one's contribution by $\$ 1$ may have a different significance when, for instance, the base contribution was $\$ 0$ as opposed to $\$ 9$. The tobit model may capture the fact that students could not give more than $\$ 10$ or less than $\$ 0$ : in students' overall generosity, there may be censoring relative to the range we assign in the experiment.

In all specifications, OLS, ordered probits and tobits, we find similar results. We find significant effects of the voucher on students' gifts to charities. The marginal effects in the tobit model are even larger than the marginal effects reported in Table 4a.

\footnotetext{
${ }^{20}$ Harbaugh, et al. [2002] report regressions that do and do not control for height. The lower generosity of boys disappears when they control for height. However, since we did not measure height, we compare our results to those in which the previous study also did not control for height.
} 


\section{Discussion: Mechanisms for the Observed Voucher Effect on Altruism}

We found that voucher winners give more to charities than voucher losers but not more to peers. These reduced-form findings tell us the net impact of the voucher program (i.e., the effect of the "intention-to-treat”). These effects may have been caused by several potential mechanisms. While the voucher program we investigated was not designed to identify a particular mechanism, we can speculate on a few possible mechanisms as a guide to future research and program design. ${ }^{21}$ Previous research discusses a variety of mechanisms by which vouchers may affect students including private schooling [Rouse 1998], student incentives [Angrist et al. 2002], peer effects [Hsieh and Urquiola 2003], and income shocks [Angrist et al. 2002]. In addition, mechanisms such as reciprocity and inequity aversion [Bolton and Ockenfels 2000 and Fehr and Schmidt 1999] may also explain these reduced-form findings. The voucher program we investigated allows us to consider three of these possible mechanisms: private schooling, reciprocity, and inequity aversion.

\section{Private Schooling}

Private schooling is one potential way the voucher may have affected students. Voucher recipients were twice as likely to attend private school as a result of the voucher. Identifying the effect of private school is difficult since selection bias precludes direct comparisons of voucher lottery participants who attended or did not attend private school. Even if we had data for other private school students who may appear similar to lottery participants but who did not apply for vouchers, there may be unobserved characteristics that led to the application for the voucher lottery (e.g. parental motivation).

\footnotetext{
${ }^{21}$ Most voucher research provides little discussion of the possible mechanisms because of the difficulty in identifying an unbiased estimate of the effects of a specific mechanism [e.g. Angrist et al. 2002].
} 
We can test, however, whether private schools is the only mechanism by which the voucher had an effect. To conduct this test, recall that some students were already attending private school prior to the voucher lottery. If the voucher lottery did not affect the future likelihood of attending private school among these students, and private schooling is the only mechanism through which the voucher affected behavior, then among these students winning the voucher lottery should have no effect.

To proceed, recall that CSF conducted two lotteries - one among families with children currently enrolled in private school and another among families without children enrolled in private school. Among the families in the "private lottery," most students continued to attend (77 percent of losers, 82 percent of winners, t-stat on difference equals 0.53 ). Thus, the voucher lottery did not affect the likelihood of private school attendance among applicants in the "private lottery." Further, there were also a small number of participants who were in the public school lottery but had previous private school experience and should have participated in the private lottery. The voucher had no effect on their private school attendance patterns either. Among these "previously private school" applicants, voucher winners experienced a modest income shock (1/2-tuition per child in private school) and the voucher may have affected their feelings toward reciprocity or inequity aversion (discussed below) ${ }^{22}$ However, if private school is the only driving force behind the voucher effect, then we would expect to see no effect of the voucher among these students since there is no difference in private school attendance patterns for them.

We examine this hypothesis by regressing the amount students gave against voucher status identical to the regressions presented in Table 4a except we examine only the students who had been attending private school prior to the voucher lottery. In these regressions (with 43 students and 27

\footnotetext{
${ }^{22}$ The $1 / 2$ tuition savings averaged $\$ 1,141$. There is also no evidence that voucher winners "traded up" to more expensive private schools. Almost all the voucher winners in this group continued to attend the same private school they attended prior to the lottery.
} 
families), we find positive effects of the voucher. In the stacked regressions without covariates, the voucher effect on giving to charities is positive (1.60) but not significant ( $t=1.38, \mathrm{p}=.167)$. In the stacked regressions with covariates, the effect is positive (2.16) and significant (t-stat=2.17, $\mathrm{p}=.030$ ). These results suggest that private schooling cannot be the sole force behind our reduced-form results. At least among these students there are other mechanisms driving the effects of the voucher. There still could be a private school effect that raised donations for the students who were not previously in private schools, but other mechanisms besides, or in addition to, private schooling may be driving differences in the amounts given to charities among these voucher winners and losers.

In sum, our results cannot reject or confirm that there is a private schooling effect. It can, however, establish that other factors besides, or in addition to, private schooling are present.

\section{Reciprocity}

One of these other mechanisms by which the voucher affected students may be the result of voucher winners reciprocating the gift received from the Children's Scholarship Fund. If the amount children gave is motivated by reciprocity to the non-profit organizations, then we might expect the largest increase in the amount given by lottery winners than lottery losers to occur for CSF since this would be direct reciprocity (to the organization that provided them with the scholarship) whereas the amount given to the Red Cross and Make-A-Wish would be indirect reciprocity. Past research generally finds that direct reciprocity is greater than indirect reciprocity (see Bolton, Katok and Ockenfels 2004 and references therein). However, Table 4a shows that the estimated mean additional amount that lottery winners gave to the Red Cross and Make-A-Wish $\{\$ 0.85$ $[=(\$ 1.19+\$ 0.51) / 2]\}$ is greater than the additional amount lottery winners gave to CSF $(\$ 0.71)$. Further, among voucher winners, the average donation to CSF was nominally smaller but not statistically different from their donations to Make-A-Wish or the Red Cross. Moreover, among the 
students who were already attending private schools, the estimated effect is nearly identical for the additional amount given to each charity by voucher winners than voucher losers. These results suggest that if reciprocity is the motivation explaining why lottery winners gave more to charities, then the students did not make a distinction between direct and indirect reciprocity.

If there is no distinction between direct and indirect reciprocity, but reciprocity is a mechanism for the voucher effect for the charities, then another potential way to test for reciprocity is to examine the effect of the voucher on parental giving since parents were not exposed to the schooling but yet were beneficiaries of the charity. This strategy implicitly assumes that parents and children have a similar psychology of giving.

Table 5 reports the stacked regressions on the effects of the voucher for parents' choices. In this case, we find no significant effects of the voucher on the amount parents gave to charities or peers. The point estimates on the amount that parents gave to the charities is in fact negative in the OLS and ordered probit specifications, but insignificant $(\mathrm{p}>.20)$. If the psychology of giving is similar for parents and children, then the fact that voucher winning parents did not respond by giving more money to charities like the students responded suggests two possible explanations. First, student's altruism may be more malleable than adults. This explanation is consistent with the literature suggesting altruism is still developing during these student years [e.g. Bryan and Walbek 1968, Froming 1985, Harbaugh and Krause 2000]. Second, the voucher effect in children is more likely the result of some other voucher mechanism than reciprocation for being voucher lottery winners.

A final reciprocity explanation might be that the reduced-form voucher effect is driven by lowering the losers' level of reciprocity rather than by increasing the winners’ level of reciprocity. For instance, voucher lottery losers may have sought to "punish" CSF for having not selected them and consequently caused them to give less. This punishment theory, however, seems unlikely for a 
few reasons. First, if voucher lottery losers were punishing CSF, we would expect them to give the least to CSF; however, voucher losers gave more to CSF than to the Red Cross. Second, this theory would require that applicants remember losing the voucher lottery. However, when we interviewed applicants (the parents), we asked them if they remembered applying and whether they won or not, and over 2/3 of voucher lottery losers did not recall the process of applying nor did they recall whether they had lost the voucher lottery. This is not too surprising given it was extremely easy to apply; families only needed to call a toll-free number and answer a short set of questions. Further, after applying families only received communication from CSF if they won. Given that more than 2/3 of parents did not recall applying, it seems perhaps even less likely that children would recall losing the lottery 3 to 4 years before our sessions were run. For these reasons, it seems unlikely that the losing the voucher lottery caused less charitable actions.

In sum, we cannot find evidence that the voucher effect was due to direct rather than indirect reciprocity (i.e. the voucher effect did not have the biggest affect in the amount given to CSF); however, we cannot reject that the voucher effect arises from indirect reciprocity (i.e. giving to charities in general versus only to CSF). Further, we argued that if reciprocity is the cause of the reduced-form results, it is unlikely to be due to negative reciprocity of voucher losers decreasing the amount they gave.

\section{Inequity Aversion}

Another possible explanation for increased gifts by voucher winners may be that voucher winners attempted to reduce negative utility due to inequity aversion [e.g., Bolton and Ockefels 2000 or Fehr and Schmidt 1999]; inequity aversion implies that individual i receives utility $\mathrm{u}_{\mathrm{i}}\left(\mathrm{x}_{\mathrm{i}}, \mathrm{x}_{\mathrm{j}}\right)$ from outcomes to themselves, $x_{i}$, and person $\mathrm{j}, \mathrm{x}_{\mathrm{j}}$, such that $\mathrm{u}_{\mathrm{i}}$ is increasing in their own outcomes $\mathrm{x}_{\mathrm{i}}$ but decreasing in inequity $\left|\mathrm{x}_{\mathrm{i}}-\mathrm{x}_{\mathrm{j}}\right|$. If participants' utility of their own outcome is concave and they are 
better off than the receiver of their giving, then to reduce the negative effect of inequity on utility, participants would give more to others the better off they are and the worse off the recipients are. There is some support for inequity aversion in our data. For instance, inequity averse subjects would give less money to their peers as the exchange rate increased to reduce the inequity of the outcomes. Consistent with this prediction, we found a negative though insignificant decrease in the amount given to others as the exchange rate increased. ${ }^{23}$ Further, inequity averse subjects would also be expected to give more money to charities than to peers if the recipients of the charities are perceived as more disadvantaged than their peers (who they know little about). Again, consistent with this prediction, voucher lottery winners and losers (parents and students) gave more to charities than to their peers.

With respect to inequity arising from the voucher, voucher winners may have felt "more privileged," and consequently the same division of money may have seemed more inequitable to the voucher winners than losers. In this case, we would expect the voucher winners to give more to others to reduce the voucher winner's perceived greater inequity. While this inequity aversion is consistent with voucher winners giving more than voucher losers to the charities, it seems inconsistent with other results we have found. For instance, we would expect this inequity aversion to hold for the amounts sent to peers also since there should be no difference among voucher winners and losers in expectations regarding peers, but we found that winners and losers sent to similar amounts to their peers. Further, we would also expect to observe this inequity aversion in the parents' decisions, yet we found that parents of voucher winners and losers sent the same amount

\footnotetext{
${ }^{23}$ For these children, giving less the higher the exchange rate will maximize utility (i.e., give $\$ 6$ or $\$ 7$ when the exchange rate is $50 \%$ so each child receives almost $\$ 3.50$, give $\$ 5$ when the exchange rate is $100 \%$ so each child receives $\$ 5$, and give $\$ 4$ when the exchange rate is $150 \%$ so each child receives \$6.00). Additional evidence consistent with this behavior is presented in Andreoni and Vesterlund [2001] using college students and theoretical developments are in Charness and Rabin [2002].
} 
to the charities. ${ }^{24}$ Thus, inequity aversion explains some of the observed behavior, but it is not clear that it provides a mechanism to explain the differential behavior between lottery winners and losers.

In sum, there are several potential mechanisms that may underlie the reduced form effect that voucher lottery winners gave more to charitable organizations than voucher lottery losers. We know from the results among the students who were previously attending private school that there are other mechanisms besides, or in addition to, private schooling that may affect the students. Further, although we cannot definitively preclude reciprocity as a mechanism, we find evidence suggesting direct reciprocity is not driving our results.

\section{Conclusion}

Education research largely focuses on the effects of interventions on student test scores.

However, educational interventions may affect other academic and non-academic outcomes. Using experimental economic methods, this paper documents the significant effects of an educational intervention on the amount children give to charities. This result, in conjunction with virtually no correlation between test scores and this altruism, suggests that studies that primarily focus on test scores can understate the overall effect of educational intervention.

We do not find voucher effects on the amount children give to other children, suggesting that the voucher effect on altruism does not extend to all forms of giving. We also find that voucher lottery winners on average gave the same additional amount to each charity than voucher losers and no significant voucher effects on parent's generosity to charities, both suggesting that children’s increased altruism towards charities may not be driven by reciprocity but rather by some other

\footnotetext{
${ }^{24}$ Although it is clear that voucher lottery winners are "better off" by having the option to use the scholarship (compared to not having the option), the effect of winning the voucher on disposable income is ambiguous since the scholarship only pays $1 / 2$-tuition. Families who won the voucher lottery and then chose to enroll their children in private school might be less well off financially since they still pay half of the private school tuition. For these families, disposable income may be lower than that of voucher lottery losers who kept their children in public school. Thus, if participants are inequity averse, then the poorer voucher lottery winning families may indeed prefer to give less than voucher lottery losers.
} 
mechanism such as increased schooling. However, we also found that among students who were in private school at the time of the lottery that voucher lottery winners also gave more than voucher lottery losers, suggesting that there are other mechanisms in addition to private schooling that may account for the increased altruism towards the charities. We hope that future voucher programs are designed such that researchers can clarify the role of reciprocity and private schooling as specific voucher mechanisms.

While the experimental methods and protocols used in the current study were developed primarily to test theory, the current paper presents an alternative use for these methods. The paper combines these methods with modern program evaluation techniques and exploits a natural experiment to demonstrate the possible effects of an educational program on altruism. Moreover, the use of experimental methods allowed us to measure altruism in a more timely and reliable way than we would have been able to measure it had we used traditional measures of charitable giving (e.g. charitable donations on tax records or through household expenditure surveys).

In addition to our main contributions, we report several results regarding children’s behavior that extend this growing literature [e.g., Harbaugh et al. 2000, 2001, 2002, and 2003]. We confirm several previous findings regarding children’s behavior using an ethnically diverse urban group of children. We also find results previously only observed in the literature for adults: children give more to charitable organizations than they give their peers. Finally, we find that age and gender are important covariates for altruism: girls gave more than boys to their peers, while older children gave more to charities. Thus, behaviors observed in experimental economic studies of adults are observed with children who are in their $1^{\text {st }}-8^{\text {th }}$ grade years. 
Appendix 1. Description of data collection.

\section{Applicant Data and Lottery}

The national headquarters of the Children's Scholarship Fund collected the applicant list and conducted the randomization. They assigned families random numbers and then released winners' names in three separate waves. The first wave was the largest and included most winners. Applicants received notification of the award by mail and phone. Applicants were required to submit tax records to verify income eligibility. After seeing that many scholarships would not be claimed, the national headquarters released a second wave of names and eventually a small third wave. There were 39 winners who did not appear in the applicant list yet all received the scholarship. A majority of these families had children previously attending private school. It is not clear when these people were added and whether these people were added at the national or local levels. Because of potential non-randomness, we excluded these people in our analyses. Our estimates of the effects of the voucher on generosity do not change when we include these people.

\section{Experimental Procedures}

We collected all outcomes single blind (subjects are unaware of what choices other subjects make) and single anonymous (subjects are unaware of the objective of the experiment). To avoid bias, the experimenters were unaware of the subjects' voucher status during the experiments. We also simultaneously and separately collected similar experimental measures for parents.

We compensated each parent \$15 in cash for attending and each child \$5 in Toys-R-Us gift certificates. Towards the end of our data collection procedures, we increased the show-up fee to $\$ 50$. In all of our regressions, we include session fixed effects to control for differences across sessions, including differences in the show-up fee. We do not report session effects since they are a function of the show-up fee, the types of individuals attending the meeting, and any influence that might distinguish one session from another (e.g. different sets of individuals, times, or dates of our data collection). Other researchers have found that compensating children with money may not hold children's attention as effectively as compensating them with toys. Not only do some children, especially young ones, not fully comprehend the value of money, but children may also fear that their parents will confiscate their earnings or at least partially influence how the money will be spent. All of the children in our sample were familiar with Toys-R-Us store. The use of Toys' R Us gift certificates may not fully eliminate the concern that parents will ultimately influence the children's purchases, but it mitigates it.

In addition to the show up fee, we compensated parents and students for decisions they made during the session. Each decision had tangible, financial consequences. Since we examine several measures, and since the subjects' incomes are low, we reduced possible wealth effects by using a random selection payment mechanism across most of the tasks, including all generosity choices. The random selection payment mechanism is a common experimental economics procedure to control for wealth effects (see Davis and Holt 1993).

Most events were conducted within groups (101 families), although a few sessions were conducted privately with individual families (26 families). In our regression analysis, we control for the type of session that students attended to account for any differences in behavior that may result from these different types of sessions. In the group sessions, we randomly and anonymously chose one or more participants at the end of each session to compensate for each decision. We selected the specific number of participants to compensate for every decision so that within each session a subject's decision for each set of tasks had approximately the same likelihood (about 1 in 5 chance) of being selected for compensation. When conducting individual sessions and at the end of all tasks, we randomly selected one task to compensate the subjects. We informed all subjects of these procedures before they made any decisions.

In the parent room, we administered the generosity tasks followed by a manipulation check and attitudinal survey which is available upon request. In the manipulation check, we asked parents to assess on a scale from 1 (strongly disagree) to 5 (strongly agree) whether they felt that the procedures had preserved anonymity, had confidence that we would pay the money as promised, and whether the instructions were clear and easy to follow. The average responses were $4.63,4.63$, and 4.78 respectively. Only three parents 
(2.4 percent) gave a response less than 3 for any of these statements and over 90 percent of all responses were 4 or 5 .

The specific schedule and order of tasks we ran for each session were identical and were as follows:

1. Registration

a. Parents and children randomly given identification tags

b. Consent and Accent Forms Provided, Read and Signed

2. Everyone gathered in "central” room

a. Refreshments (fruit, drinks, cookies) available

b. Informal description of where each family member would be located

3. Subjects separated into different rooms where decision-making data were collected:

\begin{tabular}{lcccc}
\hline \hline Decision-Making Events & $\begin{array}{l}1^{\text {st }}-2^{\text {nd }} \\
\text { Graders }\end{array}$ & $\begin{array}{l}\text { Higher } \\
\text { Grades }\end{array}$ & Parents & $\begin{array}{c}\text { Time (in } \\
\text { minutes) }\end{array}$ \\
\hline $\begin{array}{l}\text { 1. Penny jar guessing game } \\
\text { (ice-breaker event) }\end{array}$ & Yes & Yes & Yes & 15 \\
$\begin{array}{l}\text { 2. Generosity to Non-profit } \\
\text { Organizations }\end{array}$ & Yes & Yes & Yes & 15 \\
$\begin{array}{l}\text { 3. Generosity to Peers } \\
\begin{array}{l}\text { 4. Other experimental data } \\
\text { collected for related projects }\end{array}\end{array}$ Yes & Yes & Yes & 10 \\
$\begin{array}{l}\text { 5. Standardized achievement } \\
\text { Test }\end{array}$ & Yes & Yes & Yes & 30 \\
$\begin{array}{l}\text { 6. Survey: manipulation } \\
\text { checks and attitudinal } \\
\text { indicators. Plus informal } \\
\text { discussion }\end{array}$ & No & No & Yes & 10 \\
\hline \hline
\end{tabular}

4. Everyone returns to central room

a. Pizza, fruit, cookies and beverages provided

b. Parents and children called one at a time for private payments 
Appendix 2. Children's Decision-making sheet for the American Red Cross dictator game.

The Organization you are put together with for this decision is:

(First Decision) The American Red Cross

The American Red Cross tries to make people's lives better. It tries to make people's lives better by helping people be prepared for disasters, such as fires, earthquakes and flooding. The American Red Cross also helps people survive after a major disaster by providing food and a place to sleep.

\section{(Second Decision) Make-A-Wish}

Make-A-Wish tries to do something very special for children who have very bad health. The bad health usually causes the children to live fewer years than other people. What Make-A-Wish does is let's these children to do something that they especially want to do, such as go to Disneyland or to meet someone very special.

\section{(Third Decision) The Children's Scholarship Fund of Toledo}

The Children's Scholarship Fund provides money to families that want to send their children to a school of their choice. The families that the Children's Scholarship Fund usually tries to help sometimes do not have enough money to be able to send their children to the school they would want to send them to.

I want to divide the $\$ 10$ in Toys-R-Us gift certificates as follows (mark one choice only):

\begin{tabular}{|c|c|c|}
\hline My Choice & \multicolumn{2}{|c|}{$\begin{array}{c}\text { KEEP } \\
\text { For Myself }\end{array}$} \\
\hline & $\$ 10$ & $\$ 0$ \\
\hline & $\$ 9$ & $\$ 1$ \\
\hline & $\$ 8$ & $\$ 2$ \\
\hline & $\$ 7$ & $\$ 3$ \\
\hline & $\$ 6$ & $\$ 4$ \\
\hline$\$ 5$ & $\$ 5$ \\
\hline & $\$ 4$ & $\$ 7$ \\
\hline & $\$ 2$ & $\$ 8$ \\
\hline & $\$ 1$ & $\$ 10$ \\
\hline
\end{tabular}

Do you want the organization to send you a thank you letter? No Yes 


\section{References}

Andreoni, James, "Why Free Ride? Strategies and Learning in Public Goods Experiments," Journal of Public Economics, XXXVII (1988), 291-304.

Andreoni, James, Eleanor Brown and Isaac Rischall, "Charitable Giving by Married Couples: Who Decides and Why Does it Matter?" Journal of Human Resources, XXXVIII (2003), 111-133.

Andreoni, James and Lise Vesterlund, "Which is the Fair Sex? Gender Differences in Altruism," Quarterly Journal of Economics, CXVI (2001), 293-312.

Angrist, Joshua, “Conditional Independence in Sample Selection Models.” Economic Letters, LIV(2) (1997), 103-112.

Angrist, Joshua and Alan Krueger, "Empirical strategies in labor economics”, in Orley Ashenfelter and David Card, eds., Handbook of Labor Economics, III (1999), 1277-1366

Angrist, Joshua, Eric Bettinger, Eric Bloom, Elizabeth King, and Michael Kremer, "Vouchers for Private Schooling in Colombia: Evidence from a Randomized Natural Experiment", American Economic Review, XCII(5) (2002), 1535-1558.

Becker, Gary, Human Capital: A Theoretical and Empirical Analysis, with Special Reference to Education (Chicago, IL: The University of Chicago Press, 1993).

Bergstrom, Theodore, Larry Blume and Hal Varian, “On the Private Provision of Public Goods,” Journal of Public Economics, XXIX (1986), 25-49.

Bertrand, Marianne and Sendhil Mullainathan. "Are Emily and Greg more Employable than Lakisha and Jamal? A Field Experiment on Labor Market Discrimination,” American Economic Review, 94:4, (2004), 991-1013.

Bettinger, Eric, and Robert Slonim (2004), Bettinger, Eric, and Robert Slonim (2004), "Patience Among Children: Evidence from a Field Experiment,” Working Paper, Case Western Reserve University.

Bolton, Gary, and Axel Ockenfels, "ERC: A Theory of Equity, Reciprocity and Competition.” American Economic Review, XC (2000), 166-193.

Bolton, Gary, Elena Katok and Axel Ockenfels, “How effective are Electronic Reputation Mechanisms? An Experimental Investigation.” Management Science, 50(11) (2004), 15871602.

Bowles, Samuel, Herbert Gintis and Melissa Osborne, "Incentive-Enhancing Preferences: Personality, Behavior and Earnings,” American Economic Review, XCI(2) (2001), 155-158.

Bryan, J. and N. Walbek, "Preaching and Practicing Generosity: Children's Actions and Reactions." Child Development, XLI (1968), 329-353.Charness, Gary, and Mathew Rabin, "Understanding Social Preferences.” Quarterly Journal of Economics, CXVII (2002), 817-869.

Davis, Douglas and Charles Holt, "Experimental Economics: Methods, Problems, and Promise," Estudios Economicos, VIII(2) (1993), 179-212.

Dynan, Karen, Jonathon Skinner and Stephen Zeldes, "The Importance of Bequests and Life-Cycle Saving in Capital Accumulation: A New Answer." American Economic Review, XCII(2) (2002), 274-278.

Eckel, Catherine and Philip Grossman, “Altruism in Anonymous Dictator Games” Games and Economic Behavior, XVI (1996), 181-191. , and - , “Are Women Less 
— - and - "Rebate versus matching; does how we subsidize charitable contributions matter,

"Journal of Public Economics, LXXXVII (2003), 681-701.

Eckel, Catherine and Philip Grossman and M. Rachel Johnston, "An Experimental test of the crowding out hypothesis,” Forthcoming, Journal of Public Economics (2005).

Eckel, Catherine, Cathleen Johnson and Claude Montmarquette, "Human Capital Investment by the Poor: Calibrating Policy with Laboratory Experiments,” SRDC Working Paper (2005).

Fehr, Ernst, Urs Fischbacher, Bernhard von Rosenbladt, Jürgen Schupp, and Gert G. Wagner, “A NationWide Laboratory: Examining Trust and Trustworthiness by Integrating Behavioral Experiments into Representative Survey," CESifo Working Paper Series Number 866, IZA Discussion Paper Number 715 (2003).

Fehr, Ernst, Schmidt, Klaus, “A Theory of Fairness, Competition and Cooperation,” The Quarterly Journal of Economics 114 (1999), 817-868.

Fehr, Ernst and Klaus Schmidt, "Fairness, Incentives and Contractual Choices,” European Economic Review, XLIV(2) (2000), 393-421.

Fershtman, Chiam and Uri Gneezy, "Discrimination in a Segmented Society: An Experimental Approach,” The Quarterly Journal of Economics, CXVI (2001), 351-377.

Figlio, David and Jens Ludwig, "Sex, Drugs, and Catholic Schools: Private Schooling and Non-Market Adolescent Behaviors," NBER Working Paper Number 7990 (2000).

Froming, William, L. Allen and R. Jensen, “Altruism, Role-Taking, and Self-Awareness: The Acquisition of Norms Governing Altruistic Behavior.” Child Development, LVI(5) (1985), 1223-1228.

Greene, Jay, “Civic Values in Public and Private Schools,” Chapter in Learning from School Choice, Paul Peterson and Bryan Hassel eds. Washington, D.C., Brookings Institution Press (1998).

, “A Survey of Results from Voucher Experiments: Where We Are and What We Know.” Civic Report No. 11, Center for Civic Innovation, The Manhattan Institute, New York, NY (2000).

Harbaugh, William, and Kate Krause, "Children’s Altruism in Public Good and Dictator Experiments," Economic Inquiry, XXXVIII(1) (2000), 95-109.

Harbaugh, William, Kate Krause, and Tim Berry, "GARP for kids: On the development of rational choice behavior,” American Economic Review, XCI(5) (2001), 1539-1545.

Harbaugh, William, Kate Krause and Steve Liday, "Bargaining by Children,” University of Oregon, Department of Economics, Working Paper (2002).

Harbaugh, William, Kate Krause, Steven Liday, and Lise Vesterlund, “Trust in Children,” Chapter in Trust, Reciprocity and Gains from Association Elinor Ostrom and James Walker eds. New York City, Russell Sage Foundation, (2003)

Harrison, Glenn and David Kennison, “A School Voucher Scheme, Parental Education Empowerment for South Carolina,” University of South Carolina, (1993).

Harrison, Glenn, Morten Lau and Melanie Williams, "Estimating Individual Discount Rates for Denmark: A field experiment,” American Economic Review, XCII (2002), 1606-1617

Heckman, James, “Policies to Foster Human Capital,” Research Economics, LIV(1) (2000), 3-56.

Hoffman, Elizabeth, Kevin McCabe, Vernon L. Smith, “Social Distance and Other-Regarding Behavior in Dictator Games,” American Economic Review, LXXXVI(3) (1996), 653-660.

Hsieh, Chang, and Miguel Urquiola, "When schools compete, how do they compete? An assessment of Chile’s nationwide voucher program,” NBER Working Paper No. 10008 (2003). 
Jacob, Brian, and Lars Lefgren, "Are Idle Hands the Devil's Workshop? Incapacitation, Concentration, and Juvenile Crime," American Economic Review, 93(5) (2003), 1560-1577.

Jouvet, Pierre-Andre, Philippe Michel, and Pierre Pestieau, "Altruism, Voluntary Contributions and Neutrality: The Case of Environmental Quality." Economica, LXVII (2000), 465-475.

Karlan, Dean, "Using Experimental Economics to Measure Social Capital and Predict Finance Decisions," forthcoming in The American Economic Review, (2003).

Krueger, Alan and Pei Zhu, "Another Look at the New York City Voucher Experiment," NBER Working Paper Number 9418 (2003).

Levy, Frank, Richard Murnane and John Willett, "The Growing Importance of Cognitive Skills in Wage Determination," Review of Economics and Statistics, (1995).

List, John, “The Nature and Extent of Discrimination in the Marketplace: Evidence from the Field,"Quarterly Journal of Economics, CXIX (2004), 49-89.

List, John, and David Lucking-Reiley, "Demand Reduction in Multi-Unit Auctions: Evidence from a Sportscard Field Experiment," American Economic Review, XC(4) (2000), 961-972.

— Evidence from a University Capital Campaign,” Journal of Political Economy, CX(1) (2002), 215233.

Lucking-Reiley, David, “Using Field Experiments to Test Equivalence Between Auction Formats: Magic on the Internet," American Economic Review, LXXXIX(5) (1999), 1063-1080.

MacDonald, Maurice and Sun-Kang Koh, "Consistent Motives for Inter-family Transfers: Simple Altruism." Journal of Family and Economic Issues, XXIV (2003), 73-97.

Midlarsky, E and J. Bryan, "Training Charity in Children." Journal of Personality and Social Psychology, V (1967), 408-415.

Myers, David, Paul Peterson, Daniel Mayer, Julia Chou, and William G. Howell, "School Choice in New York after Two Years: An Evaluation of the School Choice Scholarships Program." Harvard's PEPG Occasional Paper Series (2000).

Mayer, Daniel, Paul Peterson, David Myers, Christina C. Tuttle, and William G. Howell, "School Choice in New York after Three Years: An Evaluation of the School Choice Scholarships Program." Harvard's PEPG Occasional Paper Series (2002).

Neal, Derek, "The Effect of Catholic Secondary Schools on Educational Achievement." Journal of Labor Economics, XV(1) (1997), 98-123.

Rouse, Cecilia Elena, "Private School Vouchers and Student Achievement: An Evaluation of the Milwaukee Parental Choice Program." The Quarterly Journal of Economics, CXIII (1998), 553-602.

Slonim, Robert and Eric Bettinger (2005), “The Effect of Educational Vouchers on Confidence: A field experiment to assess outcomes of educational policy,” in Field Experiments in Economics, Jeffrey Carpenter, Glenn W. Harrison and John A. List, eds., Greenwich, CT: JAI Press, Research in Experimental Economics, Volume 10, p291-336.

Williams, David D., Stephen C. Yanchar, Larry C. Jensen, and Cheryl Lewis, "Character Education in a Public High School: A Multi-year Inquiry into Unified Studies." Journal of Moral Education, 32(1) (2003), 3-33. 
Table 1

Personal Characteristics and Voucher Status. CSF 1998 Applicants

\begin{tabular}{|c|c|c|c|c|}
\hline \multirow[t]{2}{*}{ Dependent Variable } & \multicolumn{2}{|c|}{ Public School Lottery } & \multicolumn{2}{|c|}{ Private School Lottery } \\
\hline & $\begin{array}{l}\text { Loser's } \\
\text { Mean } \\
\text { (1) }\end{array}$ & $\begin{array}{l}\text { Diff for } \\
\text { Winners } \\
\text { (2) }\end{array}$ & $\begin{array}{l}\text { Loser's } \\
\text { Mean } \\
\text { (3) }\end{array}$ & $\begin{array}{l}\text { Diff for } \\
\text { Winners } \\
\text { (4) }\end{array}$ \\
\hline \multicolumn{5}{|l|}{ A. Applicant List } \\
\hline Income & $\begin{array}{c}21,782 \\
(14,738)\end{array}$ & $\begin{array}{l}-2,179 * * * \\
(885)\end{array}$ & $\begin{array}{c}25,740 \\
(14,032)\end{array}$ & $\begin{array}{c}2,665^{* * *} \\
(1,168)\end{array}$ \\
\hline Household Size & $\begin{array}{c}3.7 \\
(1.4)\end{array}$ & $\begin{array}{l}-.066 \\
(.093)\end{array}$ & $\begin{array}{c}3.7 \\
(1.6)\end{array}$ & $\begin{array}{l}.284^{* *} \\
(.127)\end{array}$ \\
\hline $\begin{array}{l}\text { Proportion w/ Any Child Previously } \\
\text { Attending Private School }\end{array}$ & $\begin{array}{l}.103 \\
(.304)\end{array}$ & $\begin{array}{l}.013 \\
(.021)\end{array}$ & $\begin{array}{l}.966 \\
(.182)\end{array}$ & $\begin{array}{l}.011 \\
(.015)\end{array}$ \\
\hline $\mathrm{N}$ & 331 & 1126 & 1085 & 1259 \\
\hline \multicolumn{5}{|l|}{ B. Attempted Survey Sample } \\
\hline Income & $\begin{array}{c}20,944 \\
(15,094)\end{array}$ & $\begin{array}{c}169 \\
(1,460)\end{array}$ & $\begin{array}{c}25,652 \\
(16,115)\end{array}$ & $\begin{array}{c}1,297 \\
(4,481)\end{array}$ \\
\hline Household Size & $\begin{array}{c}3.7 \\
(1.3)\end{array}$ & $\begin{array}{c}0.18 \\
(0.14)\end{array}$ & $\begin{array}{c}3.6 \\
(1.2)\end{array}$ & $\begin{array}{c}0.01 \\
(0.32)\end{array}$ \\
\hline $\begin{array}{l}\text { Proportion w/ Any Child Previously } \\
\text { Attending Private School }\end{array}$ & $\begin{array}{l}0.10 \\
(.30)\end{array}$ & $\begin{array}{l}.037 \\
(.033)\end{array}$ & 1 & -- \\
\hline Survey Response Rate & .61 & $\begin{array}{l}.06 \\
(.05)\end{array}$ & .72 & $\begin{array}{l}-.15 \\
(.14)\end{array}$ \\
\hline $\mathrm{N}$ & 200 & 390 & 25 & 48 \\
\hline \multicolumn{5}{|l|}{ C. Survey Sample } \\
\hline Income & $\begin{array}{c}21,379 \\
(15,025)\end{array}$ & $\begin{array}{c}679 \\
(1,786)\end{array}$ & $\begin{array}{c}24,335 \\
(15,320)\end{array}$ & $\begin{array}{c}961 \\
(4,927)\end{array}$ \\
\hline Household Size & $\begin{array}{c}3.7 \\
(1.4)\end{array}$ & $\begin{array}{l}.26 \\
(.18)\end{array}$ & $\begin{array}{c}3.6 \\
(1.3)\end{array}$ & $\begin{array}{c}0.37 \\
(0.41)\end{array}$ \\
\hline $\begin{array}{l}\text { Proportion w/ Any Child Previously } \\
\text { Attending Private School }\end{array}$ & $\begin{array}{l}.123 \\
(.330)\end{array}$ & $\begin{array}{l}.025 \\
(.043)\end{array}$ & 1 & -- \\
\hline Single Parent Household & $\begin{array}{l}.393 \\
(.491)\end{array}$ & $\begin{array}{l}.036 \\
(.062)\end{array}$ & $\begin{array}{l}.500 \\
(.514)\end{array}$ & $\begin{array}{l}-.115 \\
(.185)\end{array}$ \\
\hline One parent is College Grad & $\begin{array}{c}.230 \\
(.422)\end{array}$ & $\begin{array}{c}.067 \\
(.056)\end{array}$ & $\begin{array}{c}.333 \\
(.485)\end{array}$ & $\begin{array}{l}-.103 \\
(.167)\end{array}$ \\
\hline Oldest Child Attended Private (if Applied) & $\begin{array}{c}.400 \\
(.492)\end{array}$ & $\begin{array}{l}.105 \\
(.070)\end{array}$ & $\begin{array}{c}.875 \\
(.342)\end{array}$ & $\begin{array}{c}.125 \\
(.086)\end{array}$ \\
\hline African-American & $\begin{array}{c}.574 \\
(.045)\end{array}$ & $\begin{array}{c}-.144^{* *} \\
(.063)\end{array}$ & $\begin{array}{c}.278 \\
(.461)\end{array}$ & $\begin{array}{l}-.047 \\
(.163)\end{array}$ \\
\hline $\mathrm{N}$ & 122 & 250 & 18 & 31 \\
\hline
\end{tabular}

Standard deviations appear in Columns 1 and 3. Standard errors appear in Columns 2 and 4. Unit of observation is a family applying for the scholarship program. The sample size in Columns 1 and 3 is for the population of unsuccessful lottery applicants. The sample in Columns 2 and 4 is the sample of both winners and losers. 
Table 2

Children's Characteristics, Event Attendance and Voucher Status

\begin{tabular}{|c|c|c|c|c|c|}
\hline & \multicolumn{2}{|c|}{ Survey Sample Means } & \multirow{2}{*}{$\begin{array}{c}\text { Event } \\
\text { No-Show } \\
\text { (3) }\end{array}$} & \multirow{2}{*}{$\begin{array}{l}\text { Diff for } \\
\text { Event Attenders } \\
\text { (4) }\end{array}$} & \multirow{2}{*}{$\begin{array}{l}\text { Diff for Winners } \\
\text { (w/i Attenders) } \\
\text { (5) }\end{array}$} \\
\hline & $\begin{array}{l}\text { Loser's Mean } \\
\text { (1) }\end{array}$ & $\begin{array}{l}\text { Diff For Winners } \\
\text { (2) }\end{array}$ & & & \\
\hline Age & $\begin{array}{l}10.1 \\
(2.7)\end{array}$ & $\begin{array}{l}-.11 \\
(.26)\end{array}$ & $\begin{array}{l}10.2 \\
(2.9)\end{array}$ & $\begin{array}{l}-.342 \\
(.263)\end{array}$ & $\begin{array}{c}.013 \\
(.385)\end{array}$ \\
\hline Male & $\begin{array}{c}.447 \\
(.498)\end{array}$ & $\begin{array}{c}.049 \\
(.047)\end{array}$ & $\begin{array}{c}.446 \\
(.498)\end{array}$ & $\begin{array}{c}.064 \\
(.047)\end{array}$ & $\begin{array}{l}.123 * \\
(.072)\end{array}$ \\
\hline Grade & $\begin{array}{c}4.4 \\
(2.6)\end{array}$ & $\begin{array}{l}-.02 \\
(.25)\end{array}$ & $\begin{array}{c}4.5 \\
(2.6)\end{array}$ & $\begin{array}{l}-.278 \\
(.251)\end{array}$ & $\begin{array}{c}.139 \\
(.374)\end{array}$ \\
\hline Black & $\begin{array}{c}.546 \\
(.499)\end{array}$ & $\begin{array}{c}-.170 * * * \\
(.046)\end{array}$ & $\begin{array}{c}.411 \\
(.493)\end{array}$ & $\begin{array}{l}.099 * * \\
(.046)\end{array}$ & $\begin{array}{c}-.155^{* *} \\
(.068)\end{array}$ \\
\hline Private Lottery & $\begin{array}{l}.110 \\
(.314)\end{array}$ & $\begin{array}{c}.005 \\
(.029)\end{array}$ & $\begin{array}{c}.106 \\
(.309)\end{array}$ & $\begin{array}{c}.014 \\
(.030)\end{array}$ & $\begin{array}{l}.112^{* *} \\
(.044)\end{array}$ \\
\hline $\mathrm{N}$ & 218 & 471 & 263 & 471 & 208 \\
\hline
\end{tabular}

Standard deviations appear in Columns 1 and 3. White standard errors appear in Columns 2, 4 and 5 in parentheses. The unit of observation is the child applying for the scholarship program. $\left({ }^{*},{ }^{* *},{ }^{* *}: \mathrm{p}<.10, \mathrm{p}<.05, \mathrm{p}<.01\right.$, respectively.) 
Table 3

Children's Characteristics and Voucher Status. CSF 1998 Applicants

\begin{tabular}{lccc}
\hline \hline Dependent Variable & $\begin{array}{c}\text { Loser's Mean } \\
(1)\end{array}$ & $\begin{array}{c}\text { Diff for Winners } \\
\text { With No Covar } \\
(2)\end{array}$ & $\begin{array}{c}\text { Winners' Diff } \\
\text { With Basic Covs } \\
(3)\end{array}$ \\
\hline \hline Private School at time of Survey & $\begin{array}{c}.208 \\
(.407)\end{array}$ & $\begin{array}{c}.227^{* * *} \\
(.042)\end{array}$ & $\begin{array}{c}.208^{* * *} \\
(.040)\end{array}$ \\
Attended Private Since 1997 & .389 & $.261^{* * *}$ & $.243^{* * *}$ \\
& $(.489)$ & $(.046)$ & $(.043)$ \\
Ever Repeated & .218 & -.058 & -.052 \\
& $(.414)$ & $(.039)$ & $(.039)$ \\
Suspensions & .184 & $-.080 * *$ & $-.063^{* *}$ \\
Math Scores (N=349) & $(.389)$ & $(.034)$ & $(.031)$ \\
& 48.5 & .970 & .111 \\
$\mathrm{~N}$ & $(22.7)$ & $(3.37)$ & $(3.53)$ \\
& & & 466 \\
\hline
\end{tabular}

Standard deviations appear in Column 1. White standard errors appear in Columns 2 and 3. Unit of observation is a child applying for the scholarship program. Covariates include age, gender, race, family income, private school lottery dummy, and session dummies. The math scores include two observations for 163 students who took both parts of a test and 23 observations for students who took only one part of the test in our pilot. $\left(*,{ }^{* *},{ }^{* * *}: \mathrm{p}<.10, \mathrm{p}<.05, \mathrm{p}<.01\right.$, respectively.) 
Table 4a

OLS Estimates of Voucher Effects on Children's Generosity

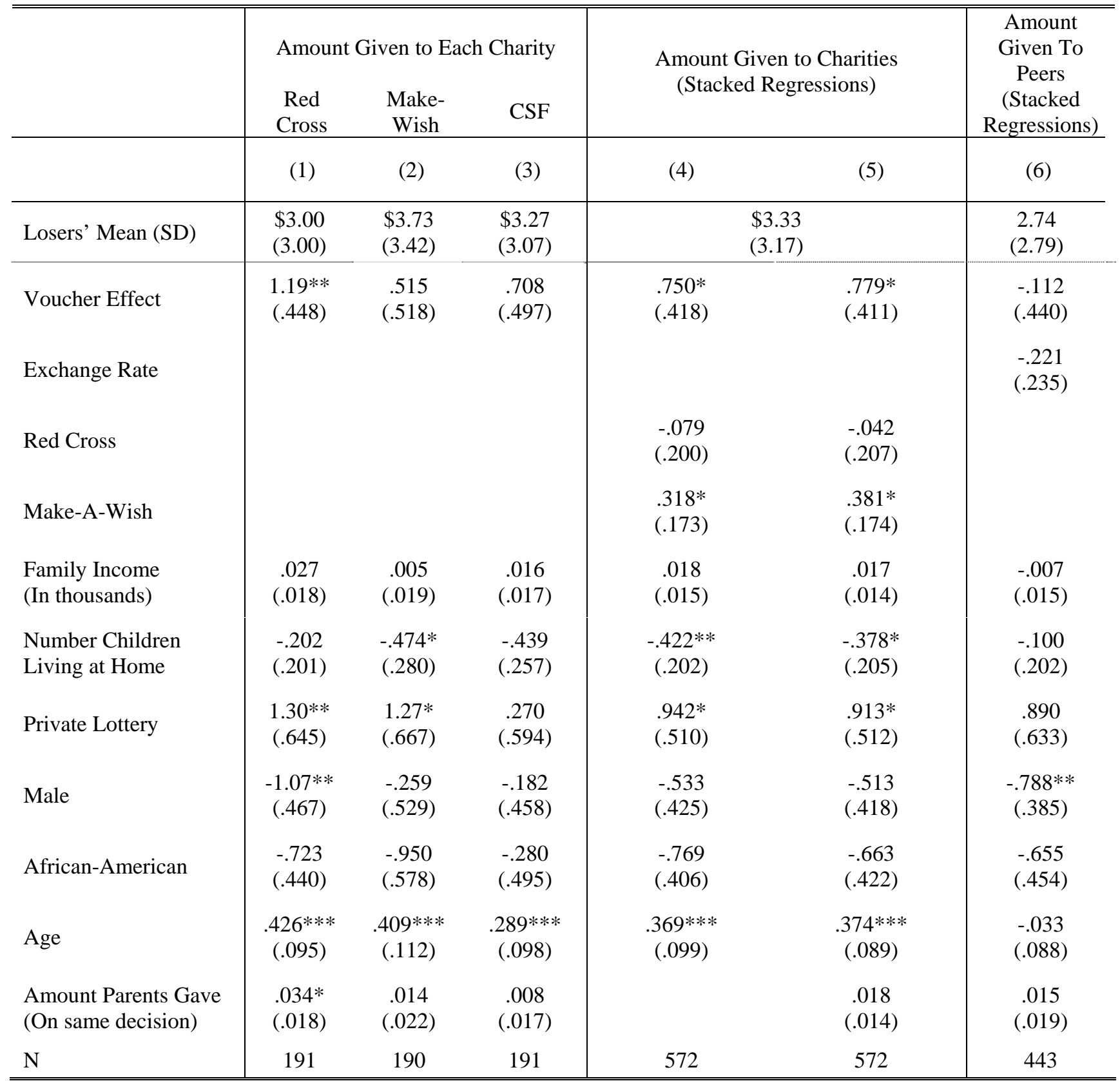

Notes: Standard errors clustered within families reported in parentheses, session effects not reported.

$(*, * *, * * *: \mathrm{p}<.10, \mathrm{p}<.05, \mathrm{p}<.01$, respectively.) 
Table 4b

Alternate Specification of Voucher Effects on Children's Generosity

\begin{tabular}{|c|c|c|c|c|}
\hline & \multicolumn{2}{|c|}{$\begin{array}{l}\text { Amount Given to charities } \\
\text { (Stacked Regressions) }\end{array}$} & \multicolumn{2}{|c|}{$\begin{array}{c}\text { Amount Given To Peers } \\
\text { (Stacked Regressions) }\end{array}$} \\
\hline & $\begin{array}{l}(1) \\
\text { O. Probit }\end{array}$ & $\begin{array}{c}(2) \\
\text { Tobit }\end{array}$ & $\begin{array}{l}(3) \\
\text { O. Probit }\end{array}$ & $\begin{array}{c}(4) \\
\text { Tobit }\end{array}$ \\
\hline Losers’ Mean (SD) & \multicolumn{2}{|c|}{$\begin{array}{l}\$ 3.33 \\
(3.17)\end{array}$} & \multicolumn{2}{|c|}{$\begin{array}{c}2.74 \\
(2.79)\end{array}$} \\
\hline Voucher Effect & $\begin{array}{l}.272 * \\
(.157)\end{array}$ & $\begin{array}{l}1.16^{* *} \\
(.492)\end{array}$ & $\begin{array}{l}.013 \\
(.184)\end{array}$ & $\begin{array}{l}.207 \\
(.573)\end{array}$ \\
\hline Exchange Rate & & & $\begin{array}{l}-.034 \\
(.100)\end{array}$ & $\begin{array}{l}-.275 \\
(.275)\end{array}$ \\
\hline Red Cross & $\begin{array}{l}-.039 \\
(.078)\end{array}$ & $\begin{array}{l}-.078 \\
(.228)\end{array}$ & & \\
\hline Make-A-Wish & $\begin{array}{l}.110^{*} \\
(.064)\end{array}$ & $\begin{array}{l}.516^{* *} \\
(.227)\end{array}$ & & \\
\hline $\begin{array}{l}\text { Family Income } \\
\text { (In thousands) }\end{array}$ & $\begin{array}{l}.004 \\
(.005)\end{array}$ & $\begin{array}{l}.010 \\
(.017)\end{array}$ & $\begin{array}{l}-.003 \\
(.006)\end{array}$ & $\begin{array}{l}-.005 \\
(.020)\end{array}$ \\
\hline $\begin{array}{l}\text { Number Children } \\
\text { Living at Home }\end{array}$ & $\begin{array}{l}-.101 \\
(.073)\end{array}$ & $\begin{array}{l}-.055 \\
(.267)\end{array}$ & $\begin{array}{l}-.034 \\
(.086)\end{array}$ & $\begin{array}{l}.113 \\
(.293)\end{array}$ \\
\hline Private Lottery & $\begin{array}{l}.360 * * \\
(.177)\end{array}$ & $\begin{array}{l}.212 \\
(.586)\end{array}$ & $\begin{array}{l}.310 \\
(.270)\end{array}$ & $\begin{array}{c}1.15 \\
(.941)\end{array}$ \\
\hline Male & $\begin{array}{l}-.161 \\
(.156)\end{array}$ & $\begin{array}{c}-1.36 * * \\
(.588)\end{array}$ & $\begin{array}{c}-.324 * * \\
(.154)\end{array}$ & $\begin{array}{c}-1.58 * * \\
(.687)\end{array}$ \\
\hline African-American & $\begin{array}{l}-.219 \\
(.154)\end{array}$ & $\begin{array}{c}-1.26 * * * \\
(.422)\end{array}$ & $\begin{array}{l}-.316 \\
(.208)\end{array}$ & $\begin{array}{c}-1.47^{* *} \\
(.715)\end{array}$ \\
\hline Age & $\begin{array}{c}.144^{* * *} \\
(.032)\end{array}$ & $\begin{array}{c}.477 * * * \\
(.113)\end{array}$ & $\begin{array}{c}.001 \\
(.033)\end{array}$ & $\begin{array}{l}-.058 \\
(.093)\end{array}$ \\
\hline $\begin{array}{l}\text { Amount Parents Give } \\
\text { (On same decision) }\end{array}$ & $\begin{array}{l}.007 \\
(.005)\end{array}$ & $\begin{array}{l}.054 \\
(.054)\end{array}$ & $\begin{array}{l}.026 \\
(.039)\end{array}$ & $\begin{array}{l}-.051 \\
(.102)\end{array}$ \\
\hline $\mathrm{N}$ & 572 & 572 & 443 & 443 \\
\hline
\end{tabular}

Notes: Ordered Probit controls for correlation with families. Tobit includes effects for children, session effects not reported. Tobit regressions censored at giving $\$ 0$ and $\$ 10$. $(*, * *, * * *: \mathrm{p}<.10, \mathrm{p}<.05, \mathrm{p}<.01$, respectively.) 


\section{Table 5}

Voucher Effects on Parents' Generosity

\begin{tabular}{|c|c|c|c|c|c|c|}
\hline & \multicolumn{3}{|c|}{$\begin{array}{l}\text { Amount Given to Charities } \\
\text { (Stacked Regressions) }\end{array}$} & \multicolumn{3}{|c|}{$\begin{array}{l}\text { Amount Given To Peers } \\
\text { (Stacked Regressions) }\end{array}$} \\
\hline & $\begin{array}{l}(1) \\
\text { OLS }\end{array}$ & $\begin{array}{l}(2) \\
\text { O. Probit }\end{array}$ & $\begin{array}{c}(3) \\
\text { Tobit }\end{array}$ & $\begin{array}{l}(4) \\
\text { OLS }\end{array}$ & $\begin{array}{l}\text { (5) } \\
\text { O. Probit }\end{array}$ & $\begin{array}{l}(6) \\
\text { Tobit }\end{array}$ \\
\hline Losers’ Mean (SD) & & $\begin{array}{l}\$ 32.37 \\
(16.49)\end{array}$ & & & $\begin{array}{l}\$ 20.93 \\
(7.86)\end{array}$ & \\
\hline Voucher Effect & $\begin{array}{l}-1.71 \\
(2.83)\end{array}$ & $\begin{array}{l}-.116 \\
(.127)\end{array}$ & $\begin{array}{l}.950 \\
(1.85)\end{array}$ & $\begin{array}{l}.458 \\
(1.52)\end{array}$ & $\begin{array}{l}.077 \\
(.123)\end{array}$ & $\begin{array}{l}.847 \\
(.727)\end{array}$ \\
\hline Exchange Rate & & & & $\begin{array}{c}-6.11 * * * \\
(.553)\end{array}$ & $\begin{array}{l}-1.20 \\
(.148)\end{array}$ & $\begin{array}{c}-6.20 * * * \\
(.527)\end{array}$ \\
\hline Red Cross & $\begin{array}{c}-2.09 * * \\
(1.01)\end{array}$ & $\begin{array}{l}-.182 \\
(.141)\end{array}$ & $\begin{array}{c}-3.31^{* *} \\
(1.34)\end{array}$ & & & \\
\hline Make-A-Wish & $\begin{array}{l}.323 \\
(1.01)\end{array}$ & $\begin{array}{l}.008 \\
(.143)\end{array}$ & $\begin{array}{c}.609 \\
(1.36)\end{array}$ & & & \\
\hline $\begin{array}{l}\text { Family Income } \\
\text { (In thousands) }\end{array}$ & $\begin{array}{l}.094^{*} \\
(.134)\end{array}$ & $\begin{array}{l}.007 \\
(.006)\end{array}$ & $\begin{array}{l}.021 \\
(.083)\end{array}$ & $\begin{array}{l}.087 \\
(.072)\end{array}$ & $\begin{array}{l}.014 \\
(.006)\end{array}$ & $\begin{array}{c}.132 * * * \\
(.032)\end{array}$ \\
\hline $\begin{array}{l}\text { Number Children } \\
\text { Living at Home }\end{array}$ & $\begin{array}{l}-2.70 \\
(1.57)\end{array}$ & $\begin{array}{c}-.193 * * * \\
(.070)\end{array}$ & $\begin{array}{c}-3.88 * * * \\
(.847)\end{array}$ & $\begin{array}{l}.572 \\
(.845)\end{array}$ & $\begin{array}{l}.036 \\
(.068)\end{array}$ & $\begin{array}{l}.976^{* *} \\
(.408)\end{array}$ \\
\hline Private Lottery & $\begin{array}{l}-3.45 \\
(4.83)\end{array}$ & $\begin{array}{l}-.303 \\
(.213)\end{array}$ & $\begin{array}{l}-4.80^{*} \\
(2.60)\end{array}$ & $\begin{array}{c}2.61 \\
(2.59)\end{array}$ & $\begin{array}{l}.418 \\
(.209)\end{array}$ & $\begin{array}{l}.536 \\
(1.03)\end{array}$ \\
\hline Male & $\begin{array}{l}-3.62 \\
(3.90)\end{array}$ & $\begin{array}{l}-.230 \\
(.174)\end{array}$ & $\begin{array}{c}-10.48^{* * *} \\
(2.77)\end{array}$ & $\begin{array}{l}-1.13 \\
(2.09)\end{array}$ & $\begin{array}{l}-.137 \\
(.168)\end{array}$ & $\begin{array}{l}-1.35 \\
(.956)\end{array}$ \\
\hline African-American & $\begin{array}{l}-4.71 \\
(3.05)\end{array}$ & $\begin{array}{c}-.376 * * * \\
(.138)\end{array}$ & $\begin{array}{c}-11.11 * * * \\
(2.18)\end{array}$ & $\begin{array}{l}3.29 * * \\
(1.64)\end{array}$ & $\begin{array}{c}.389 \\
(.132)\end{array}$ & $\begin{array}{c}5.69 * * * \\
(.817)\end{array}$ \\
\hline Religion & $\begin{array}{l}-1.78 \\
(5.09)\end{array}$ & $\begin{array}{l}-.130 \\
(.233)\end{array}$ & $\begin{array}{c}5.12 \\
(4.43)\end{array}$ & $\begin{array}{c}-.038 \\
(2.73)\end{array}$ & $\begin{array}{c}-.045 \\
(.219)\end{array}$ & $\begin{array}{l}.105 \\
(1.12)\end{array}$ \\
\hline $\mathrm{N}$ & 333 & 333 & 333 & 333 & 333 & 333 \\
\hline
\end{tabular}

Notes: Heteroskedasticity corrected standard errors in parentheses, session effects not reported.

Tobit regressions censored at giving $\$ 0$ and $\$ 50$. (*, **, $* * *: \mathrm{p}<.10, \mathrm{p}<.05, \mathrm{p}<.01$, respectively.) 